\title{
Chemical alarm signals in wild Trinidadian guppies (Poecilia reticulata)
}

\author{
Grant E. Brown and Jean-Guy J. Godin
}

\begin{abstract}
We investigated the presence and possible function of chemical alarm signals (alarm pheromones) in wild Trinidadian guppies (Poecilia reticulata) using laboratory, trapping, and direct field observational methods. In laboratory experiments, female guppies from a population exposed to high predation significantly increased their shoaling, dashing, and freezing behaviours and significantly reduced area use when exposed to the skin extract of sympatric female guppies. When exposed to the skin extract of females from a low-predation population, female guppies from a high-predation population exhibited significant, though smaller, increases in antipredator behaviour. No significant differences in antipredator behaviours were noted when females were exposed to swordtail (Xiphophorus helleri) skin extract, which lacks any known alarm pheromone. We conducted two field experiments to confirm these laboratory results. In a trapping experiment, significantly more guppies were caught in funnel traps labelled with distilled water than in paired traps labelled with sympatric guppy skin extract. In a final experiment, a realistic model of a natural predator (pike cichlid, Crenicichla alta), paired with either sympatric guppy skin extract or distilled water, was presented to groups of free-ranging guppies in pools of a high-predation river. Significantly fewer guppies were observed within a 50-cm radius of the predator model and significantly fewer guppies inspected the model when it was paired with guppy skin extract versus distilled water. Taken together, our results strongly suggest the presence of a chemical alarm signal (alarm pheromone) in the Trinidadian guppy, establish the validity of laboratory and trapping studies in the investigation of chemical alarm signalling, and demonstrate that alarm pheromones may function to mediate predation risk under natural conditions in the guppy.
\end{abstract}

Résumé : Nous avons vérifié la présence et la fonction probable des substances d'alerte de nature chimique (phéromones d'alerte) chez des Guppys (Poecelia reticulata) sauvages de Trinidad par des expériences en laboratoire, par piégeage et par observation directe sur le terrain. En laboratoire, les femelles d'une population exposée à un fort taux de prédation augmentent significativement leurs comportements de regroupement, d'élancement et d'arrêt brusque et diminuent significativement leur zone de déplacement au contact d'extraits de peau de femelles sympatriques. Au contact d'extraits de peau de femelles d'une population exposée à un faible taux de prédation, les femelles (provenant d'une population exposée à une forte prédation) augmentent leurs comportement antiprédateurs, mais pas avec autant d'intensité. Aucune différence n'a été notée dans le comportement antiprédateurs de femelles exposées à des extraits de peau du Queue d'épée, Xiphophorus helleri (qui ne semble pas posséder de phéromone d'alerte). Nous avons procédé à deux expériences sur le terrain pour vérifier ces résultats. Lors de piégeages, un nombre significativement plus grand de guppys ont été capturés dans les pièges en entonnoirs marqués d'eau distillée que dans des pièges jumelés marqués au moyen d'un extrait de peau d'un guppy sympatrique. Enfin, dans une autre expérience, un modèle réaliste d'un prédateur naturel (cichlidé, Crenicichla alta), jumelé à un extrait de peau d'un guppy sympatrique ou à de l'eau distillée, a été présenté à des groupes de guppys en liberté dans des cuvettes d'une rivière où la prédation est forte. Il y avait significativement moins de guppys dans un rayon de $50 \mathrm{~cm}$ du modèle de prédateur et significativement moins d'entre eux ont examiné le modèle lorsque celui-ci était jumelé à de l'extrait de peau plutôt qu'à de l'eau distillée. Dans l'ensemble, nos résultats indiquent que les guppys de Trinidad possèdent une substance d'alerte chimique (phéromone d'alerte), ils confirment la validité des études de laboratoire et des techniques de piégeage comme moyens de détecter les signaux chimiques et ils démontrent que les phéromones d'alerte peuvent servir à réduire les risques de prédation dans des conditions naturelles chez le Guppy.

[Traduit par la Rédaction]

\section{Introduction}

Chemical alarm signals (alarm pheromones, as defined by Christensen and Sorensen 1996; Smith 1997a) have been demonstrated in several taxonomically diverse fishes (Pfeiffer 1977; Smith 1992), including ostariophysans (von Frisch 1938, 1941; Lawrence and Smith 1989; Mathis and Smith 1993a; Brown and Godin, 1999), sticklebacks (Mathis and

Received August 12, 1998. Accepted January 26, 1999.

G.E. Brown ${ }^{1}$ and J.-G.J. Godin. Department of Biology, Mount Allison University, 63B York Street, Sackville, NB E4L 1G7, Canada.

${ }^{1}$ Author to whom all correspondence should be sent at the following address: Department of Biological Sciences, Science and Engineering Center, Union College, Schenectady, N.Y. 12308-12311, U.S.A. (e-mail: browng@union.edu). 
Smith 1993a; Brown and Godin 1997), poecillids (Garcia et al. 1992; Nordell 1998), darters (Smith 1979), gobies (Smith 1989), sculpins (Hugie et al. 1991), salmonids (Lebedeva et al. 1994; Brown and Smith 1997), and cichlids (Wisenden and Sargent 1997). In general, these alarm signals are only released following mechanical damage to the skin as would occur during a predation event (Smith 1992), though there are examples of nondamage release alarm signalling systems (e.g., Iowa darters, Etheostoma exile; Wisenden et al. 1995a). When detected by nearby conspecifics (and some heterospecifics), alarm pheromones elicit antipredator behaviour (alarm response), including increased shoaling, shelter use, freezing, dashing, area avoidance, and reduced foraging (Heczko and Seghers 1981; Lawrence and Smith 1989; Krause 1993; Mathis and Smith 1993a; Brown et al. 1995a; Wisenden et al. 1995b).

It is well established that predation has a major influence on all aspects of the life history of the Trinidadian guppy (Poecilia reticulata; Magurran et al. 1992; Houde 1997), making the guppy a likely candidate for chemical alarm signalling (Chivers and Smith 1998). It remains uncertain if the Trinidadian guppy possesses an alarm pheromone, as there are contradictory reports (Pfeiffer 1977; Smith 1992; Nordell 1998). Nordell (1998) exposed guppies from a stocked feral population in New Mexico, U.S.A., to the odor of injured conspecifics versus a distilled water control under laboratory conditions. Her test guppies significantly increased their antipredator behaviour in response to the conspecific skin extract. However, Nordell could not rule out the possibilities that guppies may exhibit similar increases in antipredator behaviour to the odor of injured fish of any species and that her results may have been a laboratory artifact (cf. Magurran et al. 1996; Smith 1997a). Thus, the first goal of the current study was to confirm the presence of an alarm pheromone (sensu Smith 1992, 1997a; Christensen and Sorensen 1996) in the Trinidadian guppy using both laboratory and field experiments.

A variety of prey fishes, including the guppy, readily inspect potential predators based on visual cues (Pitcher 1992; Dugatkin and Godin 1992a). There are a number of potential benefits associated with predator inspection behaviour, including visual alarm signalling to nearby shoal mates (Smith and Smith 1989; Murphy and Pitcher 1997), predator deterrence (Magurran 1990; Godin and Davis 1995a, 1995b; but see also Milinski et al. 1997), and differential mating opportunities (Godin and Dugatkin 1996). One of the main hypothesized benefits of predator inspection is the acquisition of information regarding the local risk of predation (Pitcher 1992; Dugatkin and Godin 1992a). Guppies, for example, are able to discriminate between hungry and satiated predators (Licht 1989). European minnows (Phoxinus phoxinus) modify their antipredator behaviour upon inspection of a potential predator depending on the latter's behaviour (Murphy and Pitcher 1997). Though the exact mechanism for information acquisition in these species is not known, it has been suggested that the predator's behaviour may be a significant source of this information (Murphy and Pitcher 1997). Visual cues alone, however, are potentially unreliable as they can be readily manipulated by predators. The use of a second sensory modality could increase the reliability of any in- formation acquired (Smith 1997b). A likely source of information about predation risk would be prey alarm pheromones in the diet of a potential predator (Mathis and Smith 1993b, 1993c; Brown et al. 1995b).

Predator inspection based on chemical cues present in the predator's diet has recently been demonstrated in the glowlight tetra (Hemigrammus erythrozonus; Brown and Godin 1999). Shoals of tetras were initially exposed to both the odor and sight of a live novel fish predator (convict cichlid, Cichlasoma nigrofasciatum) that had been fed either tetras (possessing alarm pheromone; Pfeiffer 1977) or swordtails (Xiphophorus helleri; lacking any known alarm pheromone; Mathis and Smith 1993a). Tetras exhibited a significant increase in antipredator behaviour when exposed to the tetradiet cue, but not when exposed to the swordtail-diet cue. Chemically mediated, predator inspection behaviour was also affected. The presence of an alarm pheromone in the diet of the predator significantly increased the latency to initiate an inspection visit, increased the minimum approach distance towards the predator, and significantly decreased the number of inspectors per inspection visit. Such behaviour appears to represent a threat-sensitive trade-off between the risk of mortality associated with the presence of an alarm signal (Smith 1992) and the benefit of information acquisition about the nature of the predation threat (Dugatkin and Godin 1992a). As such, predator inspection behaviour is a suitable behavioural assay for the presence of a chemical alarm signal. Trinidadian guppies have strong predator inspection tendencies (Dugatkin and Godin 1992b; Magurran and Seghers 1994; Godin and Davis 1995a, 1995b). It is unknown if the presence of chemical alarm signals would significantly alter their predator inspection behaviour, as observed in the glowlight tetra (Brown and Godin, 1999). Therefore, the second goal of the current study was to examine the effects of the putative alarm pheromone of Trinidadian guppies on their predator inspection behaviour under natural conditions.

Despite the considerable volume of research demonstrating the existence of alarm pheromones in fishes, Magurran et al. (1996) have recently argued that there is insufficient evidence to support this conclusion. One of their major arguments is that much of the data in support of alarm pheromones comes from laboratory and trapping studies. Magurran et al. (1996) argue that these methods are ecologically invalid and yield false-positive results (see Smith 1997a for contradictory arguments). They argue that only direct field observations on fish behaviour are valid for the investigation of alarm pheromones. Hence, a third aim of our study was to investigate the presence of alarm pheromones in the Trinidadian guppy using experimental laboratory, trapping, and direct field observation methods. By employing all three of these methodologies on the same population of guppies, we hope to validate the utility of these experimental techniques in investigating alarm pheromones in aquatic animals.

If guppies possess an alarm pheromone, then we expect that they will exhibit a typical alarm response (characterized by dashing behaviour, increased shoaling tendency, and increased tendency to remain immobile), avoid areas containing alarm chemical stimuli, and become more timid (reduced tendency to inspect nearby fish predators) when exposed to a skin extract of conspecifics in general. 


\section{Methods}

\section{Experiment 1: laboratory assay}

We collected small, apparently nongravid (assessed visually) female guppies from the Quaré $\left(10^{\circ} 41^{\prime} \mathrm{N}, 61^{\circ} 11^{\prime} \mathrm{W}\right)$ and the Marianne $\left(10^{\circ} 45^{\prime} \mathrm{N}, 61^{\circ} 18^{\prime} \mathrm{W}\right)$ rivers in the Northern Range Mountains of Trinidad, West Indies, between 27-30 April 1997. The Quaré River empties into the southeast-flowing Oropuche drainage, while the Marianne River drains into the north-flowing Northern drainage. These rivers differ in the number and variety of fish predators present. The Quaré River can be considered a relatively high predation risk system as it contains several predatory species, including pike cichlid (Crenicichla alta), blue acara cichlid (Aequidens pulcher), black acara cichlid (Cichlasoma bimaculatum), Hart's rivulus (Rivulus hartii), and a predatory characin (Astyanax bimaculatus) (Liley and Seghers 1975; Magurran et al. 1992; Godin 1995). The Marianne River can be considered a low predation risk system, as the only known predators present are $R$. hartii and a predatory freshwater prawn (Macrobrachium crenulatum) (Endler and Houde 1995). Rivulus hartii is generally restricted to preying on smaller juvenile guppies (Godin 1995).

Approximately 100 females (standard length (SL), expressed as a mean $\pm \mathrm{SE}$, was $1.91 \pm 0.52 \mathrm{~cm}$ and $1.98 \pm 0.49 \mathrm{~cm}$ for the Quaré and Marianne rivers, respectively) were collected from each population using a seine net and held under laboratory conditions for a minimum of 4 days prior to testing. Guppies were housed in 37-L glass aquaria at approximately $27^{\circ} \mathrm{C}$ and exposed to a $12 \mathrm{~h}$ light (L) : $12 \mathrm{~h}$ dark (D) cycle. The water was continuously filtered and aerated. Guppies were fed ad libitum twice daily with commercial flake food.

Guppy tissue extract was prepared fresh daily, immediately prior to use. We sacrificed stimulus donor fish with a blow to the head (in accordance with the Canadian Council on Animal Care Guidelines) and immediately removed the head and tail (at the caudal peduncle). We then removed all internal visceral tissue and placed the remaining tissue (skin plus underlying skeletal muscle tissues) in $50 \mathrm{~mL}$ of distilled water. We homogenized the tissue samples, filtered the homogenate through glass wool, and added distilled water to bring the final volume to exactly $50 \mathrm{~mL}$. We collected approximately $5.2 \mathrm{~cm}^{2}$ of skin for each day's trials. This value was based on the concentrations of skin extract preparations previously reported for fathead minnows (Lawrence and Smith 1989). We generated extracts for both the Quaré River (QR) and Marianne River (MR) populations. Standard lengths of skin donors were $1.99 \pm$ $0.10 \mathrm{~cm}$ (Quaré River) and $1.86 \pm 0.11 \mathrm{~cm}$ (Marianne River).

To control for a response to the chemical stimuli from any injured fish, we tested Quaré River guppies for an alarm response to the skin extract of swordtails. Swordtails were used as a stimulus source because they lack any known alarm pheromones (Pfeiffer 1977; Mathis and Smith 1993a) and do not co-occur with guppies in Trinidad (Axelrod and Vorderwinkler 1983).

Swordtails were obtained commercially and were fed and housed as described for the guppies. We prepared swordtail skin extract (SWT) from nine donor fish $(4.67 \pm 0.14 \mathrm{~cm} \mathrm{SL})$ for a total of $25.49 \mathrm{~cm}^{2}$ of skin. SWT was prepared as described above for guppy skin extract except that distilled water was added to bring the final volume to exactly $300 \mathrm{~mL}$. This yielded a final concentration that was similar to that used for the guppy extract. The swordtail extract was frozen at $-20^{\circ} \mathrm{C}$ until required. Freezing has no known effect on the effectiveness of swordtail skin extract in behavioural assays for antipredator responses (Lawrence and Smith 1989).

We tested shoals of four female Quaré River guppies (1.93 \pm $0.08 \mathrm{~cm} \mathrm{SL})$ in a series of glass aquaria. For the QR and MR treatments, the dimensions of the test tanks measured $35(\mathrm{l}) \times 22(\mathrm{w}) \times$ $23 \mathrm{~h}) \mathrm{cm}$. For the SWT treatment, the dimensions of the tanks were $40(\mathrm{l}) \times 21(\mathrm{w}) \times 26(\mathrm{~h}) \mathrm{cm}$. Water volume was similar in all test tanks. In all treatments, the test tanks contained a gravel substrate and a single air stone. Connected to the air stone was an additional length of air tubing that allowed us to remotely inject the chemical stimulus (stimulus injection tube) from behind a black plastic viewing blind. Horizontal reference lines were drawn on the front and back wall of the tank at 5-cm intervals, thus delineating three equal vertical zones to facilitate scoring area use. We tested a total of 10 shoals for each for the QR and SWT treatments and 11 shoals for the MR treatment. Individual guppies were exposed to only one experimental treatment.

Individual shoals were observed during paired 5-min prestimulus and 5-min poststimulus periods. During both these periods, we recorded (i) an index of area use, (ii) a shoaling index, and (iii) the frequency of occurrence of dashing and freezing behaviours. Area use was recorded every $15 \mathrm{~s}$ as the sum of the location scores for each guppy $(1=$ bottom third of tank, $3=$ top third of the tank). Possible area use scores ranged from 4 (all guppies on the bottom) to 12 (all guppies at the surface). An index of shoal cohesion was also recorded every $15 \mathrm{~s}$ and ranged from 1 to $4(1=$ no guppies within one body length of each other, $4=$ all guppies within one body length of each other; modified from Mathis and Smith 1993d). Dashing is defined as a sudden burst of apparently disoriented swimming (Lawrence and Smith 1989). Freezing is defined as the cessation of all movement, with the guppy settling to the substrate and remaining motionless for at least $30 \mathrm{~s}$ (Lawrence and Smith 1989). Both of these behaviours may reduce an individual fish's immediate risk of predation (Godin 1997; Smith 1997b).

Following the prestimulus observation period, we removed and discarded $60 \mathrm{~mL}$ of water from the stimulus injection tube and then removed and retained an additional $60 \mathrm{~mL}$ of tank water. We then injected either $5 \mathrm{~mL}$ of distilled water (control trials) or $5 \mathrm{~mL}$ of QR, MR, or SWT extract (experimental trials) and slowly flushed the stimulus into the tank using the retained water. Poststimulus observation periods began as we started to inject the stimulus. Dye tests revealed that this technique results in a relatively uniform distribution of the chemical stimulus throughout the tank within approximately $20 \mathrm{~s}$. Control trials were always conducted in the morning, since any response to the experimental stimulus may have masked any response to the control stimulus (Hazlett 1997).

We calculated the difference between the prestimulus and poststimulus periods for mean area use and shoaling index scores and compared these differences between the control and experimental trials using a one-tailed paired $t$ test. To reduce the likelihood of increased type I error, we set $\alpha$ at 0.03 according to the modified Bonferroni test (Keppel 1982). Frequencies of occurrence of dashing and freezing behaviours were compared between control and experimental trials using the Fisher's exact probability test (Siegel and Castellan 1988).

\section{Experiment 2: field area labelling and trapping}

We conducted a field trapping experiment between 29 April and 4 May 1997 to determine if Quaré River guppies avoid areas labelled with conspecific skin extract (chemical alarm signal). Funnel traps were constructed using 2-L clear, plastic, soft-drink bottles. We removed the top of each bottle and reattached it with stainless steel wire to form an inverted funnel. We then drilled a $15 \times 10$ grid of small $(<3 \mathrm{~mm})$ holes in the sides of the bottle to allow water to flow through the trap.

To label the traps, we attached two small cellulose sponges $\left(2 \mathrm{~cm}^{3}\right)$ to the mouth of each trap using stainless steel wire. Control traps were labelled by injecting $20 \mathrm{~mL}$ of distilled water into the sponge, while experimental traps were similarly labelled with $20 \mathrm{~mL}$ of guppy extract.

Quaré River guppy skin extract was prepared as described in experiment 1 but with two exceptions. First, we collected approximately $25 \mathrm{~cm}^{2}$ of guppy skin diluted in $300 \mathrm{~mL}$ of distilled water. This gave us a similar chemical stimulus concentration as in exper- 
iment 1. Second, skin extract was prepared the previous day and frozen at approximately $-20^{\circ} \mathrm{C}$. As a control, we also froze $300 \mathrm{~mL}$ of distilled water at approximately $-20^{\circ} \mathrm{C}$. Skin extract and distilled water were kept frozen until about $30 \mathrm{~min}$ prior to use in the field. Freezing of minnow skin extract solutions does not reduce its effectiveness as an alarm stimulus (Lawrence and Smith 1989).

We selected five typical pools along a 300-m stretch of the Quaré River. Adjacent pools were separated by an average of $42 \mathrm{~m}$ (range: $17-90 \mathrm{~m}$ ). All pools had a similar mixed-cobble and finecobble substrate, less than $25 \%$ leaf-litter cover, and an estimated average $\left( \pm\right.$ SE) area of $298 \pm 81 \mathrm{~m}^{2}$. Traps were set in pairs (each experimental trap paired with a control trap) in each pool at approximately 09:30 and 14:30 daily over 5 consecutive days. Care was taken to ensure that pairs of traps were set in similar conditions (i.e., substrate, ambient light, and current), that the location of the control and experimental traps was alternated between sets, and that the control and experimental traps were at least $10 \mathrm{~m}$ apart. In addition, we ensured that the traps were set in different locations within each pool for each set. This yielded a total of 50 trap pairs. Pairs of traps were set approximately $15 \mathrm{~min}$ apart to allow sufficient time to collect the traps and count any fish caught. Traps were set for $1 \mathrm{~h}$. At the end of this period, the traps were removed from the pool and the number of adult male, adult female, and juvenile guppies in each trap were enumerated. Captured fish were then released into the river. Prior laboratory tests confirmed that any trapped guppies remain in our traps for at least $5 \mathrm{~h}$ (G.E. Brown and J.-G.J. Godin, personal observations), which exceeds the 1-h set period.

Pairs of traps in which neither the control nor the experimental trap caught any guppies were deleted from the analysis, yielding a total of 30 usable trap pairs (equal to $60 \%$ of traps set). The number of guppies caught was compared using a three-way ANOVA with time of day, day of experiment, and treatment as independent variables. To determine if there was any difference in the ratio of adult males, adult females, and juveniles caught in control versus experimental traps, we compared the ratio of fish caught to an expected ratio using the $G$ test (Sokal and Rohlf 1981). Expected ratios were based on the mean number of adult males, adult females, and juveniles that we captured (presumably haphazardly) in at least two seine hauls through each pool upon completion of the trapping study.

\section{Experiment 3: field predator model presentation}

To test the effects of chemical alarm signals on predator inspection behaviour, we presented free-ranging guppies in pools of the Quaré River (different from those in experiment 2) with a realistic model of a pike cichlid paired with either distilled water or guppy skin extract. The model was cast of a mold of a freshly killed pike cichlid (14 cm SL), realistically painted and coated with fiberglass resin (see Godin 1995 for a detailed description of this model). Guppies respond to model and live predators in a qualitatively similar manner (e.g., Magurran and Seghers 1990; Dugatkin and Godin 1992b; Godin 1995). The experiment was carried out between 30 April and 4 May 1997.

Guppy skin extract was prepared and stored as in experiment 2. From a vantage point on the bank of the river, we submerged the model, suspended from a 1-m clear Plexiglas rod by monofilament nylon lines, into a pool and held it relatively stationary about $5 \mathrm{~cm}$ above the substrate. A 3-m length of airline tubing, which was attached to a $4 \mathrm{~cm}$ long rock located under the cichlid model, was used to remotely introduce the chemical cues into the water near the model. We injected either $50 \mathrm{~mL}$ of distilled water or guppy skin extract into the line and used stream water to flush the stimulus through at a rate of approximately $5 \mathrm{~mL} / \mathrm{min}$. Prior to each trial, we positioned the stimulus injection tube near the center of the pool (depth, 25-50 cm) and positioned the model immediately above the point at which the chemical cues were to be introduced.

For each of the five pools used, we conducted paired control (distilled water) and experimental (guppy skin extract) observation periods, which lasted $10 \mathrm{~min}$ each. We observed the fish from vantage points on the banks of the pools. During both control and experimental periods, we recorded $(i)$ the number of guppies within a $50-\mathrm{cm}$ radius of the predator model every $15 \mathrm{~s}$, (ii) the number of predator inspection visits, and (iii) the occurrence of dashing behaviour (as defined in experiment 1). Predator inspection visits were defined as a directed, saltatory approach towards the predator model by a guppy (or shoal of guppies) within the $50-\mathrm{cm}$ radius centered on the predator model (sensu Dugatkin and Godin 1992a). The order of paired control and experimental trials was randomized. A total of 15 paired observations was conducted over a total of five pools.

Since movement of individual guppies between pools in Trinidadian streams appears limited (Reznick et al. 1996), we treated each pair of observations as an independent trial. Guppies within individual pools may have been exposed to the model predator a total of six times (three control and three experimental trials). We did not consider this a possible confound, since repeated exposure to the model should reduce the observed effect, making our results more conservative. We compared the median number of guppies observed within $50 \mathrm{~cm}$ of the model and the mean number of predator inspection visits towards the model between paired control and experimental periods using one-tailed paired $t$ tests. To control for the possibility of reduced predator inspection visits as a result of reduced numbers of guppies near the predator model, we calculated a per capita inspection rate by dividing the observed number of inspection visits by the mean number of guppies observed within $50 \mathrm{~cm}$ of the model for each trial and compared these values between the control and experimental treatments using a paired $t$ test. The occurrence of dashing behaviour was compared between the treatments using the Fisher's exact probability test (Siegel and Castellan 1988).

\section{Results}

\section{Experiment 1: laboratory assay}

Quaré River guppies increased their shoaling tendency when exposed to the chemical stimuli of conspecifics from the same population $(t=8.98, \mathrm{df}=9, p<0.0001$; Fig. 1A) and conspecifics from a geographically isolated population $(t=6.28, \mathrm{df}=10, p<0.0001$; Fig. 1A), but exhibited no response to chemical stimuli originating from swordtails $(t=$ 0.25 , df $=9, p=0.81$; Fig. 1A). Only the guppies exposed to sympatric skin extracts showed a significant change in area use (i.e., spent more time near or on the substrate; $t=3.11$, df $=9, p<0.02$; Fig. 1B). Quaré River guppies did not significantly alter their area use in response to chemical stimuli originating from either Marianne River guppies $(t=1.44$, $\mathrm{df}=10, p=0.18$; Fig. 1B) or swordtails $(t=0.87$, df $=9$, $p=0.41$; Fig. 1B).

In response to the chemical stimuli from both Quaré and Marianne river guppies, Quaré River guppies increased the frequency of both dashing and freezing behaviour (Table 1), but not to the chemical stimuli from swordtails (Table 1). These data clearly demonstrate that wild-caught female guppies significantly increase their antipredator behaviour (i.e., an alarm response) when exposed to conspecific skin extract, suggesting that the latter contains a putative alarm pheromone. 
Table 1. Frequencies of occurrence of dashing and freezing behaviour of Quaré River females to each of the skin extract conditions (versus distilled water controls) in experiment 1.

\begin{tabular}{|c|c|c|c|c|c|c|}
\hline \multirow[b]{2}{*}{ Skin extract source } & \multicolumn{3}{|l|}{ Dashing } & \multicolumn{3}{|l|}{ Freezing } \\
\hline & Present & Absent & $p^{a}$ & Present & Absent & $p^{a}$ \\
\hline \multicolumn{7}{|l|}{ Quaré River } \\
\hline Control & 0 & 10 & & 0 & 10 & \\
\hline Experimental & 10 & 0 & $<0.0001$ & 10 & 0 & $<0.0001$ \\
\hline \multicolumn{7}{|l|}{ Marianne River } \\
\hline Control & 0 & 11 & & 0 & 11 & \\
\hline Experimental & 8 & 3 & 0.0005 & 7 & 4 & 0.0002 \\
\hline \multicolumn{7}{|l|}{ Swordtail } \\
\hline Control & 0 & 10 & & 1 & 9 & \\
\hline Experimental & 1 & 9 & 0.50 & 1 & 9 & 0.76 \\
\hline
\end{tabular}

Note: Values are the number of trials in which dashing or freezing was observed. ${ }^{a}$ Fisher's exact probability test (Siegel and Castellan 1988).

\section{Experiment 2: field area labelling and trapping}

Traps labelled with distilled water caught a total of 130 guppies, whereas those labelled with the chemical stimuli from guppies caught only $26\left(F_{[1,40]}=11.81, p<0.002\right)$. We observed no significant effects of time of day $\left(F_{[1,40]}=0.11\right.$, $p=0.75)$ or day of the experiment $\left(F_{[4,40]}=0.25, p=0.91\right)$ on the number of fish trapped. Likewise, no significant interactions between these factors were observed. In both control and experimental trials, the ratio of adult males, adult females, and juveniles did not differ from that expected based on their relative abundance in the pools (control traps: $G=5.23, \mathrm{df}=2, p=0.08$; experimental traps: $G=0.83, \mathrm{df}=$ $2, p=0.66)$. These data clearly demonstrate that wild guppies, irrespective of age or sex, avoid areas of a natural stream that have been labelled with conspecific skin extract.

\section{Experiment 3: field predator model presentation}

Significantly fewer guppies were seen near the predator model when it was paired with guppy extract than with distilled water ( $t=2.86, \mathrm{df}=14, p<0.007$; Fig. 2A). We also observed significantly fewer predator inspection visits when the model was paired with guppy extract versus distilled water $(t=7.16$, df $=14, p<0.0001$; Fig. 2B). When we compared the number of inspection visits observed in each trial corrected for the mean number of guppies present (i.e., per capita inspection rate), we still observed a significant decrease in the skin extract versus the distilled water treatment $(t=2.04, \mathrm{df}=14, p<0.05$; Fig. 2C).

In the control trials, we observed no instances of dashing behaviour, whereas in 13 of 15 experimental trials, at least one guppy exhibited dashing (Fisher's exact probability, $p<$ $0.0001)$. These data show that predator inspection behaviour is significantly affected by the presence of a conspecific chemical alarm signal nearby.

\section{Discussion}

Taken together, our results clearly demonstrate that the Trinidadian guppy possesses a chemical alarm signal (alarm pheromone) system. Under laboratory test conditions, significant increases in antipredator behaviours were observed in the presence of chemical stimuli originating from both sympatric and allopatric conspecifics. Our trapping experi-
Fig. 1. Change in shoaling index (A) and area use scores (B) for shoals of four female Quaré River guppies exposed to either distilled water (DW; open bars) or fish skin extract (QR, Quaré River guppy extract; MR, Marianne River guppy extract; SWT, swordtail extract; closed bars). Values are given as the mean \pm SE and $p$ values are based on paired $t$ tests. $n=10$ shoals for QR and SWT trials and $n=11$ for MR trials. Increased shoaling index (more cohesive shoaling) and decreased area use scores (greater proportion of time spent near substrate) are indicative of an antipredator response.
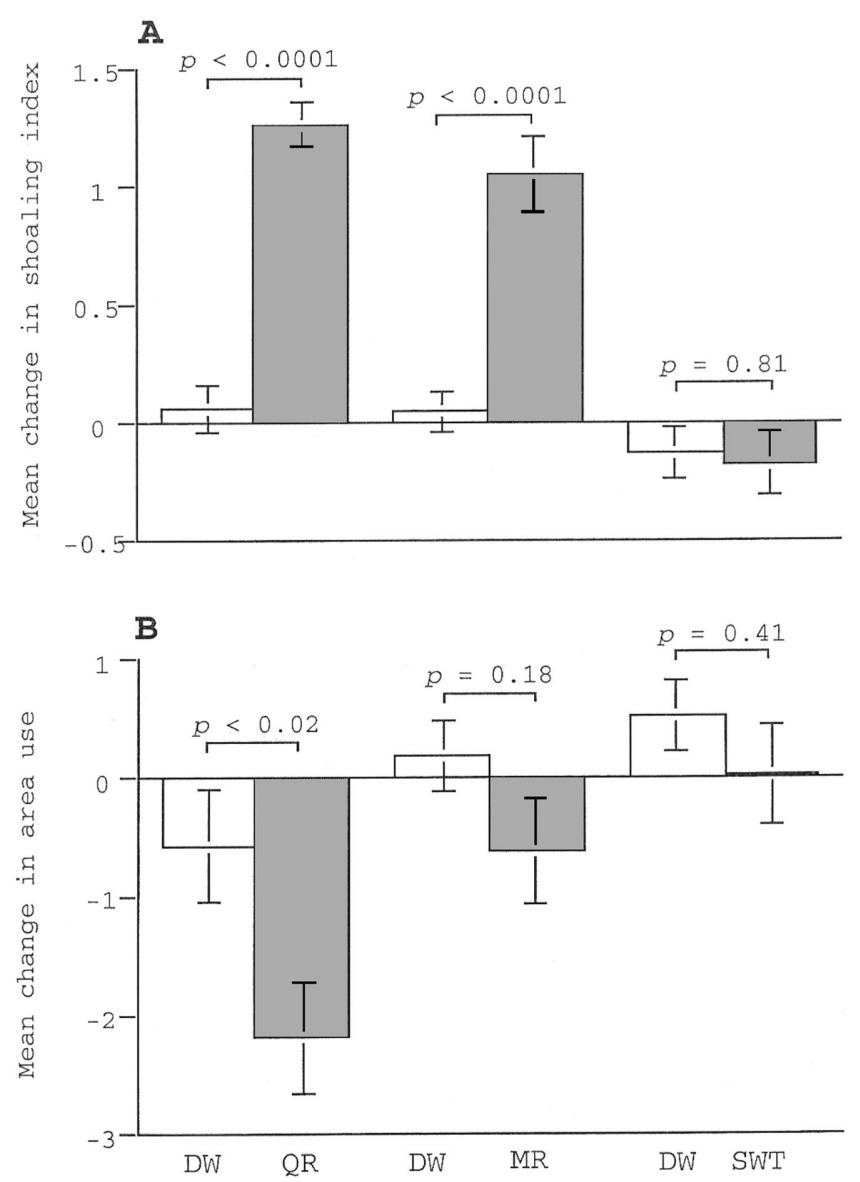
Fig. 2. Response of guppies in a natural habitat towards a predator model paired with either distilled water (DW, open bars) or Quaré River guppy extract (QR, closed bars).

(A) Median number of guppies observed every $15 \mathrm{~s}$ within $50 \mathrm{~cm}$ of the predator model. (B) Number of predator inspection visits. (C) Per capita predator inspection rates. Values are given as the mean \pm SE and $n=15$ trials. $p$ based on paired $t$ tests.
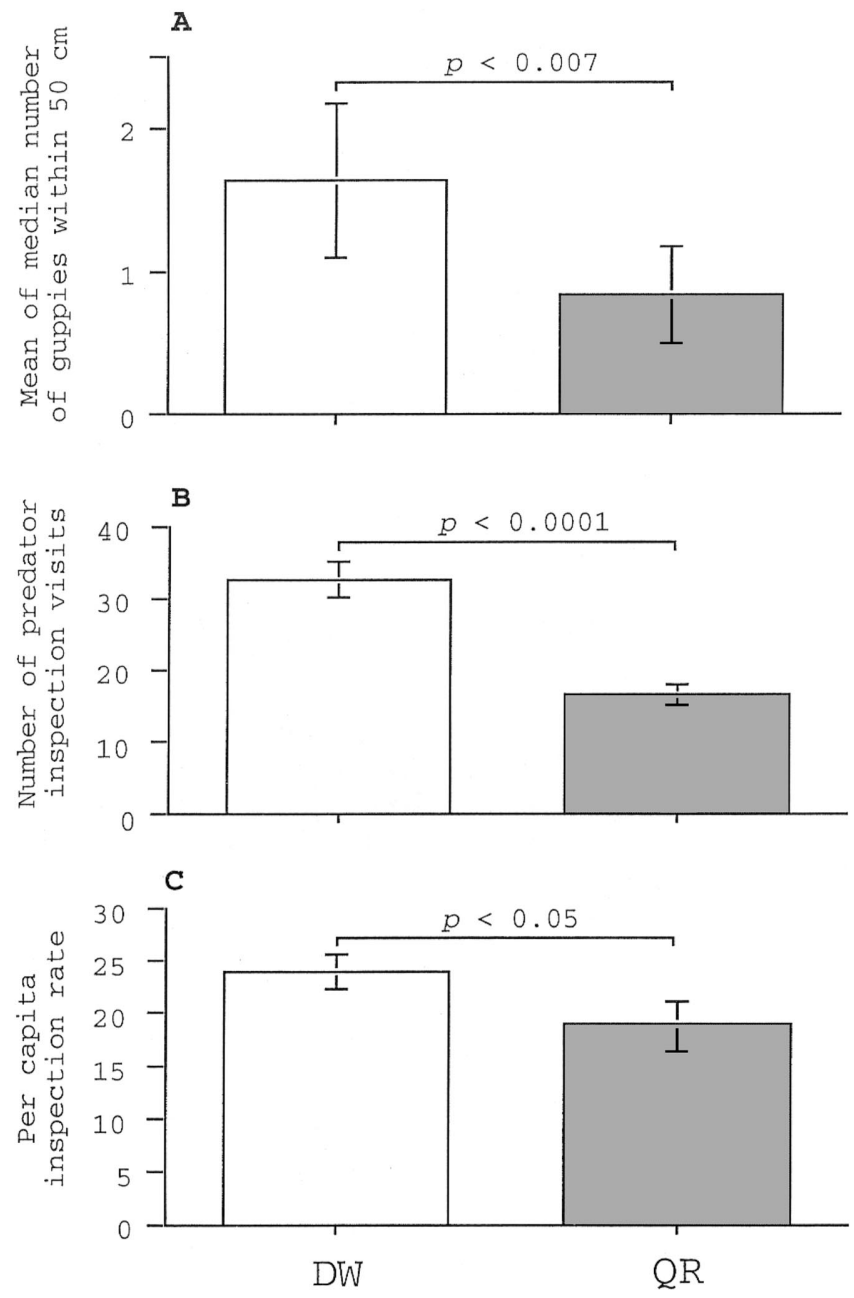

ment showed a significant (fivefold) decrease in the number of guppies caught in traps labelled with conspecific skin extracts compared with those labelled with distilled water. Finally, our direct field observations under natural conditions revealed that significantly fewer guppies were observed within $50 \mathrm{~cm}$ of a realistic predator model and fewer predator inspection visits were initiated towards the model when it was paired with guppy skin extract versus distilled water.

Our results confirm those of Nordell (1998). Nordell, however, could not conclusively state that guppies possess an alarm pheromone because she could not rule out a possible response to the chemical cues of any injured prey. Her guppies may have been simply responding to the odor of an injured fish rather than to an alarm pheromone specifically. In our study, guppies exhibited a significant increase in antipredator behaviour when exposed to conspecific skin extract, but there was no significant change in their behaviour when they were exposed to the skin extract of a species (swordtail) that lacks alarm pheromones. These data strongly suggest the presence of an alarm pheromone system in the Trinidadian guppy.

Our results further suggest that components of the guppy alarm pheromone system may be population specific. Quaré River guppies exhibited a less intense response to the skin extract of Marianne River guppies than towards Quaré River guppies, as revealed by the lack of a significant difference in area use and smaller increases in shoaling tendency and dashing and freezing behaviours. This difference in response intensity between populations may be related to differences in local predation pressure. The Quaré River is a high predation stream, with a variety of predators present, while the Marianne River is a low predator pressure stream, having only two relatively minor predators (see Introduction), and the two rivers are in separate drainages which have been isolated, apparently, for at least 500000 years (Fajen and Breden 1992). Hugie (1989) demonstrated a positive correlation between the production of alarm pheromone and the intensity of conspecific alarm responses in fathead minnows and argued that this relationship is due to differences in predation regimes between populations. Further work is required to examine this hypothesis in the Trinidadian guppy.

Our trapping experiment, similar to that employed by Mathis and Smith (1992, 1993a), Wisenden et al. (1994, $1995 a$ ), and Chivers et al. (1995b), revealed that freeranging guppies avoid areas of the river that have been labelled with guppy skin extract compared with those areas labelled with distilled water. In addition, the ratio of adult males, adult females, and juveniles did not differ from ratios reflecting their relative abundance in the pools. This strongly suggests that their response to the alarm pheromone is innate or learned at a very early stage. Chivers et al. (1995b) demonstrated a learned response to heterospecific alarm pheromones between fathead minnows and brook sticklebacks (Culaea inconstans). The role of experience was reflected by an elevated frequency of juveniles in traps labelled with heterospecific alarm pheromone, suggesting that they had not yet "learned" the cue. Such a difference was not detected in our study, suggesting that recognition of conspecific alarm signals in the Trinidadian guppy is not dependent on experience.

Guppy predator inspection behaviour was also affected by the presence of conspecific alarm pheromone. The observed decrease in predator inspection behaviour in the presence of an alarm pheromone may represent a threat-sensitive tradeoff. This trade-off, between the perceived risk of mortality (associated with the chemical alarm signal) and information gained through predator inspection behaviour about the nature of the predation threat (and other potential benefits; Dugatkin and Godin 1992a), appears to result in the inspectors becoming more wary of potential predators (as in Brown and Smith 1996). Nordell (1998) suggested that the presence of a chemical alarm signal may allow guppies to assess predation risk without inspecting a potential predator. Our data and those of Brown and Godin (1999) on tetras suggest that, rather than avoiding predators, inspectors may be assessing both the visual and chemical cues associated with a potential predator, thereby increasing the quality of 
information obtained and concurrently reducing their risk of mortality during inspection visits (cf. Magurran 1990; Godin and Davis 1995a, 1995b).

It has previously been argued that damage-released alarm pheromones represent an evolutionary anomaly because it had been unclear how the signal benefitted the signal sender (Magurran et al. 1996). However, recent studies have demonstrated that alarm pheromones may provide a variety of benefits to both signal senders and receivers (Smith 1997a, 1997b). For example, the detection of alarm pheromone in fathead minnows increases the probability of surviving an encounter with a predatory northern pike (Esox lucius), and thus represents a benefit to signal receivers (Mathis and Smith 1993d). Mathis et al. (1995) demonstrated that minnow alarm pheromone is attractive to predators (northern pike and Dytiscidae beetles). The presence of minnow alarm pheromone significantly increases prey handling time in northern pike and significantly increases the probability of prey escape, representing a benefit to the signal sender (Chivers et al. 1996).

Brown and Smith (1994) have shown that fathead minnows use chemical cues to distinguish between familiar and unfamiliar conspecifics. This may allow for long-term retention of related individuals as shoal mates (Brown and Smith 1994). Rainbow trout (Oncorhynchus mykiss) also possess chemical alarm signals (Lebedev et al. 1994; Brown and Smith 1997). They can discriminate between kin and nonkin individuals based on waterborne chemosensory cues (Brown and Brown 1992; Brown et al. 1993) and preferentially defend foraging territories near kin (Brown and Brown 1993, $1996 a, 1996 b)$. These examples suggest the possibility of kin-selected benefits associated with chemical alarm signals (Smith 1986; Brown and Smith 1997). Guppies have been shown to possess some kin discrimination abilities (Loekle et al. 1982), and thus chemical alarm signals may represent a potential kin-selected benefit to signal senders (Smith 1986; Brown and Smith 1994; Brown and Brown 1996a 1996b).

Many prey fishes do not recognize either the visual or chemical cues of a potential predator until such cues have been paired with conspecific or heterospecific alarm pheromone. Such acquired predator recognition has been demonstrated in European minnows (Magurran 1989), fathead minnows (Chivers and Smith $1994 a, 1994 b$ ), brook sticklebacks (Chivers et al. 1995a), rainbow trout (Brown and Smith 1998), and glowlight tetra (Brown and Godin, 1999). The acquired recognition of predators can be culturally transmitted, both intra- and inter-specifically, throughout a population (Mathis et al. 1996). In the case of fathead minnows, cultural transmission allows for the rapid learning of predator identity under natural conditions (Chivers and Smith 1995; Brown et al. 1997), thus increasing an individual's chance of survival upon encountering a potential predator. Information regarding predator identity and local predation risk may be culturally transmitted by guppies in a similar fashion, representing a benefit to signal receivers.

In summary, we have reported consistent results in each of the three experimental paradigms employed in the current study. As such, our data do not support the assertion of Magurran et al. (1996) that laboratory and field tests of putative alarm pheromones are invalid. The combination of direct field observations of fish and controlled laboratory and field trapping experiments provides us with powerful experimental protocols to test both proximate and functional questions about chemical alarm communication (Smith 1997a, 1997b) in the Trinidadian guppy, as well as in other aquatic animals.

\section{Acknowledgments}

We thank Professor Peter Bacon, Department of Zoology, University of the West Indies, St. Augustine, Trinidad, for replacing some of our lost equipment and the Trinidad Ministry of Agriculture, Land and Marine Resources (Fisheries Division), for permission to collect wild guppies. Financial support was provided by a McCain postdoctoral fellowship at Mount Allison University and research grants from Union College to G.E.B. and from the Natural Sciences and Engineering Research Council of Canada to J.-G.J.G. We dedicate this manuscript to the memory of Professor R. Jan F. Smith.

\section{References}

Axelrod, H.R., and Vorderwinkler, W. 1983. Encyclopedia of tropical fishes. T.F.H. Publications, Neptune City, N.J.

Brown, G.E., and Brown, J.A. 1992. Do rainbow trout and Atlantic salmon discriminate kin? Can. J. Zool. 70: 1636-1640.

Brown, G.E., and Brown, J.A. 1993. Social dynamics in salmonid fishes: do kin make better neighbours? Anim. Behav. 45: 863-871.

Brown, G.E., and Brown, J.A. 1996a. Kin discrimination in salmonids. Rev. Fish Biol. Fish. 6: 201-219.

Brown, G.E., and Brown, J.A. 1996b. Does kin-biased behaviour increase kin-biased foraging in juvenile salmonids? Behav. Ecol. 7: 24-29.

Brown, G.E., and Godin, J.-G.J. 1997. Antipredator response to conspecific and heterospecific skin extract by threespine sticklebacks: alarm pheromone revisited. Behaviour, 134: 1123-1134.

Brown, G.E., and Godin, J.-G.J. 1999. Who dares, learns: chemical inspection behaviour and acquired predator recognition in a characin fish. Anim. Behav. 57: 475-481.

Brown, G.E., and Smith, R.J.F. 1994. Fathead minnows use chemical cues to discriminate shoalmates from unfamiliar conspecifics. J. Chem. Ecol. 20: 3051-3061.

Brown, G.E., and Smith, R.J.F. 1996. Foraging trade-offs in fathead minnows (Pimephales promelas): acquired predator recognition in the absence of an alarm response. Ethology, 102: 776-785.

Brown, G.E., and Smith, R.J.F. 1997. Conspecific skin extracts elicit antipredator responses in juvenile rainbow trout (Oncorhynchus mykiss). Can. J. Zool. 75: 1916-1922.

Brown, G.E., and Smith, R.J.F. 1998. Acquired predator recognition in juvenile rainbow trout (Oncorhynchus mykiss): conditioning hatchery reared fish to recognize chemical cues of a predator. Can. J. Fish. Aquat. Sci. 55: 611-617.

Brown, G.E., Brown, J.A., and Crosbie, A.M. 1993. Phenotype matching in juvenile rainbow trout. Anim. Behav. 46: 1223-1225.

Brown, G.E., Chivers, D.P., and Smith, R.J.F. 1995a. Localized defecation by pike: a response to cyprinid alarm pheromone? Behav. Ecol. Sociobiol. 36: 105-110.

Brown, G.E., Chivers, D.P., and Smith, R.J.F. 1995b. Fathead minnows avoid conspecific and heterospecific alarm pheromone in the faeces of northern pike. J. Fish Biol. 47: 387-393.

Brown, G.E., Chivers, D.P., and Smith, R.J.F. 1997. Differential learning rates of chemical versus visual cues of a northern pike 
by fathead minnows in a natural habitat. Environ. Biol. Fishes, 49: 89-96.

Chivers, D.P., and Smith, R.J.F. 1994a. Fathead minnows, Pimephales promelas, acquire predator recognition when alarm substance is associated with the sight of an unfamiliar fish. Anim. Behav. 48: 597-605.

Chivers, D.P., and Smith, R.J.F. 1994b. The role of experience and chemical alarm signalling in predator recognition by fathead minnows, Pimephales promelas. J. Fish Biol. 44: 273-285.

Chivers, D.P., and Smith, R.J.F. 1995. Free-living fathead minnows (Pimephales promelas) rapidly learn to recognize pike (Esox lucius) as predators. J. Fish Biol. 46: 949-954.

Chivers, D.P., and Smith, R.J.F. 1998. Chemical alarm signalling in aquatic predator-prey systems: a review and prospectus. Ecoscience, 5: 338-352.

Chivers, D.P., Brown, G.E., and Smith, R.J.F. 1995a. Acquired recognition of chemical stimuli from pike, Esox lucius, by brook sticklebacks, Culaea inconstans (Osteichthyes, Gasterosteidae). Ethology, 99: 234-242.

Chivers, D.P., Wisenden, B.D., and Smith, R.J.F. 1995b. The role of experience in the response of fathead minnows (Pimephales promelas) to skin extract of Iowa darters (Etheostoma exile). Behaviour, 132: 665-674.

Chivers, D.P., Brown, G.E., and Smith, R.J.F. 1996. The evolution of chemical alarm signals: attracting predators benefits alarm signal senders. Am. Nat. 148: 649-659.

Christensen, T.A., and Sorensen, P.W. 1996. Pheromones as tools for olfactory research. Chem. Senses, 21: 241-243.

Dugatkin, L.A., and Godin, J.-G.J. 1992a. Prey approaching predators: a cost-benefit perspective. Ann. Zool. Fenn. 29: 233-252.

Dugatkin, L.A., and Godin, J.-G.J. 1992b. Predator inspection, shoaling and foraging under predation hazard in the Trinidadian guppy, Poecilia reticulata. Environ. Biol. Fishes, 34: 265-276.

Endler, J.A., and Houde, A.E. 1995. Geographic variation in female preferences for male traits in Poecilia reticulata. Evolution, 49: 456-468.

Fajen, A., and Breden, F. 1992. Mitochondrial DNA sequence variation among natural populations of the Trinidad guppy, Poecilia reticulata. Evolution, 46: 1457-1465.

Garcia, C., Rolanalvarez, E., and Sanchez, L. 1992. Alarm reaction and alert state in Gambusia affinis (Pisces, Poeciliidae) in response to chemical stimuli from injured conspecifics. J. Ethol. 10: $41-46$.

Godin, J.-G.J. 1995. Predation risk and alternative mating tactics in male Trinidadian guppies (Poecilia reticulata). Oecologia, 103: 224-229.

Godin, J.-G.J. 1997. Evading predators. In Behavioural ecology of teleost fishes. Edited by J.-G.J. Godin. Oxford University Press, Oxford. pp. 191-236.

Godin, J.-G.J., and Davis, S.A. 1995a. Who dares, benefits: predator approach behaviour in the guppy (Poecilia reticulata) deters predator pursuit. Proc. R. Soc. Lond. B Biol. Sci., 259: 193-200.

Godin, J.-G.J., and Davis, S.A. 1995b. Boldness and predator deterrence: a reply to Milinski and Boltshauser. Proc. R. Soc. Lond. B Biol. Sci., 262: 107-112.

Godin, J.-G.J., and Dugatkin, L.A. 1996. Female mating preference for bold males in the guppy, Poecilia reticulata. Proc. Natl. Acad. Sci. U.S.A. 93: 10262 - 10267.

Hazlett, B.A. 1997. The organisation of behaviour in hermit crabs: response to variation in stimulus strength. Behaviour, 134: 59-70.

Heczko, E.J., and Seghers, B.H. 1981. Effects of alarm substance on schooling in the common shiner (Notropis cornutus Cyprinidae). Environ. Biol. Fishes, 6: 25-29.
Houde, A.E. 1997. Sex, color, and mate choice in guppies. Princeton University Press, Princeton.

Hugie, D.M. 1989. An intraspecific approach to the evolution of chemical alarm signalling in the Ostariophysi. M.Sc. thesis, University of Saskatchewan, Saskatoon.

Hugie, D.M., Thuringer, P.L., and Smith, R.J.F. 1991. The response of the tidepool sculpin, Oligocottus maculosus, to chemical stimuli from injured conspecifics, alarm signalling in the Cottidae (Pisces). Ethology, 89: 322-334.

Keppel, G. 1982. Design and analysis: a researcher's handbook. 2nd ed. Prentice Hall, Englewood Cliffs, N.J.

Krause, J. 1993. The effect of 'Schreckstoff' on shoaling behaviour of the minnow: a test of Hamilton's selfish herd theory. Anim. Behav. 45: 1019-1024.

Lawrence, B.J., and Smith, R.J.F. 1989. Behavioral responses of solitary fathead minnow, Pimephales promelas, to alarm substance. J. Chem. Ecol. 15: 209-219.

Lebedeva, N.Ye., Vosilene, M.Z.Ye., and Golovkina, T.V. 1994. Aspects of stress in rainbow trout, Salmo gairdneri, release of chemical alarm signals. J. Ichthyol. 33: 66-74.

Licht, T. 1989. Discriminating between hungry and satiated predators: the response of guppies (Poecilia reticulata) from high and low predation sites. Ethology, 82: 238-243.

Liley, N.R., and Seghers, B.H. 1975. Factors affecting the morphology and behaviour of guppies in Trinidad. In Function and evolution in behaviour. Edited by G.P. Baerends, C. Beer, and A. Manning. Oxford University Press, Oxford. pp. 92-118.

Loekle, D.M., Madison, D.M., and Christian, J.J. 1982. Time dependency and kin recognition of cannibalistic behaviour among poeciliid fishes. Behav. Neural Biol. 35: 315-318.

Magurran, A.E. 1989. Acquired recognition of predator odour in the European minnow (Phoxinus phoxinus). Ethology, 82: 216-223.

Magurran, A.E. 1990. The adaptive significance of schooling as an antipredator defence in fish. Ann. Zool. Fenn. 27: 51-66.

Magurran, A.E., and Seghers, B.H. 1990. Risk sensitive courtship in the guppy (Poecilia reticulata). Behaviour, 112: 194-201.

Magurran, A.E., and Seghers, B.H. 1994. Predator inspection behaviour covaries with schooling tendency amongst wild guppy, Poceilia reticulata, populations in Trinidad. Behaviour, 128: 121-134.

Magurran, A.E., Seghers, B.H., Carvalho, G.R., and Shaw, P.W. 1992. Behavioural consequences of an artificial introduction of guppies (Poecilia reticulata) in N. Trinidad: evidence for the evolution of antipredator behaviour in the wild. Proc. R. Soc. Lond. B Biol. Sci. 248: 117-122.

Magurran, A.E., Irving, P.W., and Henderson, P.A. 1996. Is there a fish alarm pheromone? A wild study and critique. Proc. R. Soc. Lond. B Biol. Sci. 263: 1551-1556.

Mathis, A., and Smith, R.J.F. 1992. Avoidance of areas marked with a chemical alarm substance by fathead minnows (Pimephales promelas) in a natural habitat. Can. J. Zool. 70: 1473-1476.

Mathis, A., and Smith, R.J.F. 1993a. Intraspecific and crosssuperorder responses to chemical alarm signals by brook sticklebacks (Culaea inconstans). Ecology, 74: 2395-2404.

Mathis, A., and Smith, R.J.F. 1993b. Chemical labelling of northern pike (Esox lucius) by the alarm pheromone of fathead minnows (Pimephales promelas). J. Chem. Ecol. 19: 1967-1979.

Mathis, A., and Smith, R.J.F. 1993c. Fathead minnows, Pimephales promelas, learn to recognize northern pike, Esox lucius, as predators on the basis of chemical stimuli from minnows in the pike's diet. Anim. Behav. 46: 645-656.

Mathis, A., and Smith, R.J.F. 1993d. Chemical alarm signals increase the survival time of fathead minnows (Pimephales promelas) during encounters with northern pike (Esox lucius). Behav. Ecol. 4: 260-265. 
Mathis, A., Chivers, D.P., and Smith, R.J.F. 1995. Chemical alarm signals: predator-deterrents or predator-attractants? Am. Nat. 146: 994-1005.

Mathis, A., Chivers, D.P., and Smith, R.J.F. 1996. Cultural transmission of predator recognition in fishes: intraspecific and interspecific learning. Anim. Behav. 51: 185-201.

Milinski, M., Lüthi, J.H., Eggler, R., and Parker, G.A. 1997. Cooperation under predation risk: experiments on costs and benefits. Proc. R. Soc. Lond. B Biol. Sci. 264: 831-837.

Murphy, K.E., and Pitcher, T.J. 1997. Predator attack motivation influences the inspection behaviour of European minnows. J. Fish Biol. 50: 407-417.

Nordell, S.E. 1998. The response of female guppies, Poecilia reticulata, to chemical stimuli from injured conspecifics. Environ. Biol. Fishes, 51: 331-338.

Pfeiffer, W. 1977. The distribution of fright reaction and alarm substance cells in fishes. Copeia, 1977: 653-665.

Pitcher, T.J. 1992. Who dares, wins: the function and evolution of predator inspection behaviour in shoaling fish. Neth. J. Zool. 42: 371-391.

Reznick, D.N., Butler M.J., IV, Rodd, F.H., and Ross, P. 1996. Life history evolution in guppies (Poecilia reticulata) 6. Differential mortality as a mechanism for natural selection. Evolution, 50: $1651-1660$.

Siegel, S., and Castellan, N.J. 1988. Nonparametric statistics for the behavioral sciences. 2nd ed. McGraw-Hill, New York.

Smith, R.J.F. 1979. Alarm reaction of Iowa and johnny darters (Etheostoma, Percidae, Pisces) to chemicals from injured conspecifics. Can. J. Zool. 57: 1278-1282.

Smith, R.J.F. 1986. Evolution of alarm signals: role of benefits derived from retaining group members or territorial neighbours. Am. Nat. 128: 604-610.

Smith, R.J.F. 1989. The response of Asterropteryx semipunctatus and Gnatholepis anjerensis (Pisces, Gobiidae) to chemical stim- uli from injured conspecifics, an alarm response in gobies. Ethology, 18: 279-290.

Smith, R.J.F. 1992. Alarm signals in fishes. Rev. Fish Biol. Fish. 2: 33-63.

Smith, R.J.F. 1997a. Does one result trump all others? A response to Magurran, Irving and Henderson. Proc. R. Soc. Lond. B Biol. Sci., 264: 445-450.

Smith, R.J.F. 1997b. Avoiding and deterring predators. In Behavioural ecology of teleost fishes. Edited by J.-G.J. Godin. Oxford University Press, Oxford. pp. 163-190.

Smith, R.J.F., and Smith, M.J. 1989. Predator-recognition behaviour in two species of gobies, Asterropteryx semipunctatus and Gnatholepis anjerensis. Ethology, 81: 279-290.

Sokal, R.R., and Rohlf, F.J. 1981. Biometry. 2nd ed. W.H. Freeman and Co., New York.

von Frisch, K. 1938. Zur psychologie des Fische-Schwarmes. Naturwissenschaften, 26: 601-606.

von Frisch, K. 1941. Über einen Schreckstoff der Fischhaut and seine biologische Bedeutung. Z. Vgl. Physiol. 29: 46-145.

Wisenden, B.D., and Sargent, R.C. 1997. Antipredator behaviour and suppressed aggression by convict cichlids in response to injury-released chemical cues of conspecifics but not to those of an allopatric heterospecific. Ethology, 103: 283-291.

Wisenden, B.D., Chivers, D.P., and Smith, R.J.F. 1994. Risksensitive habitat use by brook stickleback (Culaea inconstans) in areas associated with minnow alarm pheromone. J. Chem. Ecol. 20: 2975-2983.

Wisenden, B.D., Chivers, D.P., and Smith, R.J.F. 1995a. Early warning in the predation sequence: a disturbance pheromone in the Iowa darter (Etheostoma exile). J. Chem. Ecol. 21: 1469-1480.

Wisenden, B.D., Chivers, D.P., Brown, G.E., and Smith, R.J.F. $1995 \mathrm{~b}$. The role of experience in risk assessment: avoidance of areas chemically labelled with fathead minnow alarm pheromone by conspecifics and heterospecifics. Ecoscience, 2: 116-122. 